\title{
Transformation of LEGO GROUP Business Model in the Digital Economy
}

\author{
L. Kapustina, O. Gaiterova*, M. Agababaev, J. Kondratenko, P. Sidelnikova \\ Ural State University of Economics, Ekaterinburg, Russia \\ ${ }^{*}$ Corresponding author. Email: gaiterra@yandex.ru
}

\begin{abstract}
The article considers the concept and structural elements of a business model, defines the directions of transformation of business models in the digital economy. Based on the case study results and the methodology of A. Osterwalder and Yv. Pigneur a canvas of the LEGO Group business model was built. The strategy of digital transformation of the company's business model is defined from nine typical strategies - the synthesis of the existing and new digital model. Changes in eight elements of the business model in the conditions of digitalization are revealed. The creation of films, video games, online platforms, a website and applications were added to the key activities. The company's value proposition has been transformed, LEGO bricks have been supplemented with digital technologies and video games. Key resources have expanded due to software for 3D modeling and application development. The channels of interaction with customers through MyLEGONetwork and gaming platforms have been modernized. The costs of $R \& D$ and support of digital tools have increased in the structure of expenses. As a result of digital transformation of the business model (monetization of content, ticket sales in cinemas) LEGO Group's revenues have grown 5 times in fifteen years.
\end{abstract}

Keywords: business model, transformation, digital economy, LEGO Group.

\section{INTRODUCTION}

The development of digital economy technologies has led to a rethinking of existing business models and the search for ways to transform them. With the emergence of innovative technologies, about $70 \%$ of existing companies strive to preserve existing technologies and business models by implementing supportive improvements. However, this is not always justified, since as a result, 62\% of companies are completely or partially replaced by innovative companies [1]. A business model can be considered not only as a process, but also as a system of interdependent activities that goes beyond the firm and allows you to create value together with partners, as well as assign a share of this value [2]. We can distinguish the approach of Casadesus-Masanell and Ricart, who consider the business model as a set of relationships between elements and logical cycles of decision-making consequences [3]. Thus, the business model can focus on management decisions regarding employees who form a unique internal structure of the company, and the coordination of their activities establishes the position of the organization in the external environment.
In general, the researchers emphasize that the key aspect of business models is the logic of the firm, that is, how it works, how it creates value for stakeholders [4]. The business model can be represented as a process of meeting the needs of customers and making a profit, a system of interrelated activities from the purchase of raw materials to the satisfaction of the final consumer. Ritter T., Lettl C. combined the main views on business models into one coherent model [5]. The authors identified four components of the business model: stakeholder groups, interaction with customers, the way of providing value and monetization.

Digital technologies and the spread of e-commerce have contributed to the spread of platforms and stimulated the transformation of companies' business models, modeling interactions between different user groups. According to a study by the Center for Digital Business at the Massachusetts Institute of Technology, digital transformation affects both the internal and external environment of the company, the value proposition, customers, value representation, monetization, company opportunities, etc. [6]. 
The development of the digital economy, the emergence of new generations of products services, and consumer needs, as well as globalization and the shortening of the product lifecycle are forcing companies to transform their business models. We have identified the following areas of transformation of the business model in the digital economy:

- Transformation of the value proposition. At the moment, social networks are widely distributed, which act as platforms for communication and allow meeting both basic communication needs and recreational needs through entertainment content. They also act as a platform for finding partners, buyers, etc.

- Transformation of methods for identifying customer needs. To better understand the needs of customers, companies can use social networks and specially developed algorithms based on big data analysis. Companies are able to combine data on customer purchases and social media activity to provide personalized sales and service, as well as offer individual product packages.

- Transformation of the ways of customer interaction. More and more companies are turning to omni-channel technology as a way of providing value, since it allows providing an integrated approach to the buyer, in which he/she independently chooses the most optimal channel for making a purchase. In particular, applications are being developed that provide self-service opportunities, saving customers' time and reducing company costs.

- Transformation of operational processes to expand the company's capabilities. The current trend is towards automation of production processes, which significantly reduces labor costs, improves product quality, increases the safety of personnel and the environment.

Therefore, in the digital economy, it becomes possible to make decisions based not only on qualitative assumptions, but using actual data in real time. Smart enterprises have become widespread, representing a production environment that can cope with the turbulence of the production process in real time through the use of a decentralized information and communication structure for managing the production process [7].

The purpose of the study is to assess the transformation of the company's business model in the conditions of digitalization using the methodology of A. Osterwalder and Yv. Pigneur on the example of the international company LEGO Group. The digital transformation of all elements of the LEGO Group business model is evaluated, changes in each element are determined in the conditions of digitalization of customer needs.

\section{MATERIALS AND METHODS}

The most well-known tool for building business models is the outline of a business model proposed by A. Osterwalder and Yv. Pigneur, which allows to visually represent its elements, their potential relationships and impact on value creation [8]. This business model tool can be used to support sustainable development through the study of the company's capabilities and the potential for innovation. The business model canvas also allows us to form the archetypes of the most successful companies, which helps new firms to use existing experience to build their own business models. Another reason for the popularity of this tool is its simplicity and visibility of the business model elements. Business model canvas divides the company's business model into nine interrelated components: value proposition, consumer segments, customer relationships, interaction channels, key resources, key activities, partners, cost structure and income streams.

The "consumer segments" element answers the questions: "Who are the most important customers of the company?", " What segments can they be divided into?" and "What are their expectations from the company?". The value proposition focuses on the key advantages of a product or service that solve customers' problems and meet their needs. Interaction channels describe how the company interacts with consumer segments and communicates its value propositions to them. Channels of interaction include direct and indirect, as well as own and partner sales channels. The "customer relationships" element describes the types of relationships that a company establishes with individual consumer segments, which can range from personal to automated relationships. Revenue streams list revenue sources and work models. Key resources include material, financial, intellectual and human resources that are of great importance for the company's activities. Key activities contain the actions of the company that are necessary for the implementation of its business model, for example, production, supply, marketing activities, etc. The "key partners" element describes the network of suppliers and partners through which the business model functions, as well as the nature of relationships with them. And the cost structure reflects fixed and variable costs. As a result, the levels of the business model show how the organization generates economic, environmental and social value.

In the era of the digital economy, companies need to respond to market challenges. As a rule, with the advent of innovations in the market, companies need to make a number of decisions: 
Should we accept the new business model in its existing form, modify it or reject it;

Should we keep the old business model, change it, or reject it.

G. Ahuja, E. Novelli proposed seven strategies for responding to market challenges, the choice of which will depend on a number of factors of the external and internal environment of the organization (Table 1) [4].

If an existing company decides not to adopt a new business model, it can maintain the existing business model using the status quo strategy, can change the existing business model to compete with the new business model, or can withdraw from the market or use existing resources and assets to work in other areas. Alternatively, an existing company can adopt a new business model and use it in parallel with the existing one, modify the existing model, synthesizing the features of the new one in it, or switch completely to the new model.

\section{RESULTS AND DISCUSSION}

The LEGO Group company began its activity in 1932 and became known as a manufacturer of LEGO bricks. However, in 2004, the LEGO Group faced the risk of bankruptcy. One of the contributing factors was the inability to meet the changed preferences of consumers - during this period, the popularity of video games increased significantly. For example, in 2003, the global video game market was estimated at more than 21 billion dollars, and online games for personal computers brought in revenue of 450 million dollars. Further, the popularity only grew - from 2000 to 2008, the gaming industry grew more than 2 times [9].

The LEGO Group's business model can be attributed to the product models, since so far the main product is sets of LEGO bricks. At the same time, the company was engaged in the development of its own theme parks, clothing, etc. However, by 2004, the excessive diversification of LEGO Group business model became obvious - buyers lost the idea of what the company is like. This also contributed to the need for modernization and digital transformation of the existing business model (Table 2). As a result, the LEGO Group has addressed to the synthesis of its own traditional business model and the business models of digital companies.

The most significant innovation was the crowdsourcing platform LEGO Ideas. It acted as a new communication channel and allowed to identify the needs of customers and involve them in the process of creating new products by voting for the launch of new products. As a result, the company has created a global network of customer interaction with the company and with each other, as well as increased the number of regular customers who are receptive to new products. LEGO Minecraft is an example of a crowdsourcing product that received 10,000 votes within 2 days, and after successful sales, further development of thematic sets followed [10]. To increase interaction with customers, the LEGO Group has also created social media platforms. One of them is My LEGO Network - a special website for children and LEGO fans. It combines a social network with games where players can advance through levels and exchange virtual prizes. In addition, LEGO decided to enter the gaming industry, but not to replace its main product - LEGO bricks, but to complement it. So, a multiplayer online game and an online platform LEGO Universe was created, which was distributed by Warner Bros. Also, LEGO creates games on the PlayStation gaming platform together with Sony Corporation.

There was also the introduction of new technologies

Table 1. Strategies for responding to market challenges [4].

\begin{tabular}{|c|c|}
\hline Strategies & Selection factors \\
\hline $\begin{array}{l}\text { Maintaining } \\
\text { the status quo }\end{array}$ & $\begin{array}{l}\text { Uncertainty in the relative effectiveness of the new business model } \\
\text { High costs for transferring resources or combining them } \\
\text { Uncertain liquidity of the company's assets outside the existing business }\end{array}$ \\
\hline $\begin{array}{l}\text { Improving } \\
\text { your own business model }\end{array}$ & $\begin{array}{c}\text { Uncertainty in the relative efficiency of two business models } \\
\text { There is a slight coincidence in the preferences of buyers } \\
\text { Approximately equal expected competitiveness of models } \\
\text { Similarity of historical development } \\
\text { High costs for transferring resources or combining them }\end{array}$ \\
\hline $\begin{array}{l}\text { Transition } \\
\text { to a double BM }\end{array}$ & $\begin{array}{l}\text { High speed of winning the market and new customers } \\
\text { Small costs for adding a new business model to the existing one and for transferring part of } \\
\text { the resources from the existing model to another }\end{array}$ \\
\hline $\begin{array}{l}\text { Synthesis } \\
\text { of two business models }\end{array}$ & $\begin{array}{l}\text { Small costs of resources transferring part from the existing BM to new } \\
\text { The small size of the new business model market } \\
\text { The high degree of novelty of the new business model and its prevalence over the existing one }\end{array}$ \\
\hline Switching & $\begin{array}{c}\text { High efficiency of the new business model with weak efficiency of the existing one, Low } \\
\text { resource transfer costs }\end{array}$ \\
\hline $\begin{array}{l}\text { Leave the market/start } \\
\text { from the beginning }\end{array}$ & $\begin{array}{c}\text { The presence of highly common assets or a large difference in the valuation of specific assets } \\
\text { A large number of areas related to the existing type of activity }\end{array}$ \\
\hline
\end{tabular}


Table 2. LEGO Group business model canvas

\begin{tabular}{|c|c|c|c|c|c|}
\hline \multirow[t]{2}{*}{$\begin{array}{l}\text { Key Partners } \\
\text { Plastic Suppliers, } \\
\text { Merlin } \\
\text { Entertainments, } \\
\text { WWF, Disney, } \\
\text { Affiliated Partners } \\
\text { New } \\
\text { Users participating } \\
\text { in the joint creation, } \\
\text { Warner Bros, Sony } \\
\text { Corporation }\end{array}$} & 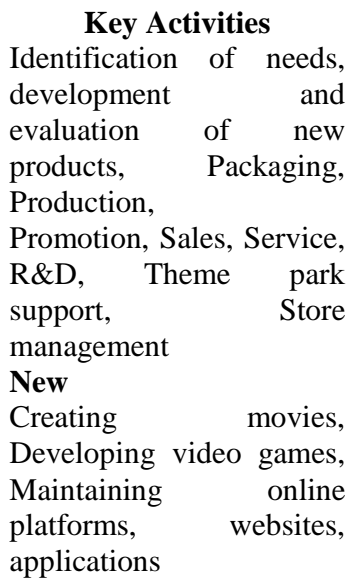 & \multirow{2}{*}{\multicolumn{2}{|c|}{$\begin{array}{l}\text { Value Proposition } \\
\text { LEGO bricks, } \\
\text { Theme parks } \\
\text { New } \\
\text { Bricks augmented } \\
\text { with technology, } \\
\text { Video Games, } \\
\text { Movies }\end{array}$}} & $\begin{array}{l}\text { Customer Relation } \\
\text { Direct sales in own and } \\
\text { retail stores, theme parks } \\
\text { New } \\
\text { Mediated through online } \\
\text { gaming platforms, The } \\
\text { possibility of joint } \\
\text { creation, Support and } \\
\text { communication through } \\
\text { social networks, Self- } \\
\text { service through a website }\end{array}$ & \multirow[t]{2}{*}{$\begin{array}{l}\begin{array}{l}\text { Consumer } \\
\text { Segments }\end{array} \\
\text { Children } \\
\text { Parents } \\
\text { School } \\
\text { Adult fans } \\
\text { Collectors }\end{array}$} \\
\hline & $\begin{array}{l}\quad \text { Key Resources } \\
\text { Brand, Plastic, } \\
\text { Theme parks, Shops } \\
\text { New } \\
\text { Software for } \quad 3 D \\
\text { modeling, } \\
\text { Website and applications }\end{array}$ & & & $\begin{array}{l}\text { Channels } \\
\text { Theme parks, Retail stores } \\
\text { New } \\
\text { Website, My LEGO } \\
\text { Network } \\
\text { Apps, Cinemas, Gaming } \\
\text { Platforms }\end{array}$ & \\
\hline \multicolumn{3}{|c|}{$\begin{array}{l}\text { Cost Structure } \\
\text { Management, Support of theme parks and own stores, } \\
\text { purchase of raw materials, product development, sales } \\
\text { organization, production, distribution, promotion } \\
\text { New } \\
\text { Content creation, R\&D, website support, online platforms } \\
\text { and applications }\end{array}$} & \multicolumn{3}{|c|}{$\begin{array}{l}\quad \text { Revenue Streams } \\
\text { Sales of goods and tickets to theme parks } \\
\text { New } \\
\text { Content monetization, licensing, movie ticket sales }\end{array}$} \\
\hline
\end{tabular}

in addition to LEGO bricks. For example, LEGO Mindstorms is a hardware and software framework for creating programmable robots based on LEGO bricks. In addition, LEGO has developed software for users to create their own sets: LEGO Digital Designer - for building models using virtual bricks and 3D modeling software for creating 2D-3D drawings from sketches.

Entering the film industry can also be considered as part of the process of digital transformation of the business model. In 2011, the LEGO Group became a partner of Warner Bros and developed the collections "The Lone Ranger", "The Hobbit", etc. LEGO also decided to create its own movies. The Lego movie was a success with a budget of 60 million dollars and a worldwide gross of 468 million dollars [11].

At the same time, the company also appealed to the digital transformation of the management system with the introduction of LEGO Digital Enterprise, which created new opportunities, consisting in rationalizing the decision-making process, focusing on the development of IT and creating a global community culture. As a result, the "Process Expert Network (PEN)" was created - a network of process experts, whose goal was to create end-to-end global processes. PEN managed the overall optimization of processes through formal audits and reviews, approval of technological documentation and data entry into business cases. At the same time, PEN also ensured the exchange of knowledge within the organization to achieve mutual understanding and consistency in all areas of business. The LEGO Group has 3 main business areas: Operations: procurement, planning, production, distribution and operational activities throughout the LEGO Group; Marketing: all commercial functions, such as product development, innovation, marketing and sales; Business support: support for the LEGO Group's general business, includes corporate finance and corporate center functions.

Thanks to the synthesis of two business models - the traditional business model for the production of LEGO bricks and a digital business model that complements the main product, the company was able to avoid bankruptcy [11]. Digital transformation and customer orientation allowed LEGO Group to optimize its management system, as well as to supplement, rather than replace, its main product with digital components. The company was included in the list of the 100 most expensive brands in the world in 2018 according to Forbes, taking the 97th place in the list with a value of 
8.6 billion dollars and brand revenue of 5.8 billion dollars [12].

According to research data, the majority of operating companies - 69\% - strive to preserve existing technologies and their own business models by implementing improvements that support them. At the same time, new players are more likely to address to innovative solutions due to low costs. As a result, 62\% of existing companies were completely or partially displaced by innovative companies [13].

\section{CONCLUSION}

It is established that the business model is understood as how the company selects consumers, forms offers for them, how it determines resources and distributes tasks between itself and partners, as well as how it creates value for the consumer and receives profit from this. Digital transformation also affects the changing of all the business model elements - the value proposition, customer segments, and ways of presenting value.

A case study of the impact of digital transformation on the business model was conducted in relation to the international company LEGO Group. All elements of the business model were transformed according to the methodology of A. Osterwalder and Yv. Pigneur. Among the key partners appeared Warner Bros, Sony Corporation. The creation of films, video games, online platforms, a website and applications were added to the key activities. The company's value proposition has been transformed, LEGO bricks have been supplemented with digital technologies and video games. Relationships with customers through online gaming platforms, social networks and a website have changed. Key resources have expanded due to software for 3D modeling and application development. The channels of interaction with customers through the MyLEGO Network and gaming platforms have been modernized. The share of $R \& D$ and the cost of maintaining a website and an online platform has increased in the structure of expenses. The revenue stream has grown due to the monetization of content, ticket sales in cinemas. As a result of the digital transformation of the business model, the LEGO Group's revenues have increased 5 times in the fifteen years since 2003. Out of nine typical strategies for changing business models, the company chose a synthesis of two business models, which is characterized by low costs of transferring part of the resources from the existing business model to the digital one and a high degree of novelty of the online platform, as well as the prevalence of the digital business model over the original model. As a result of the synthesis with the business model of the digital company, the LEGO Group changed the value proposition, the ways of identifying needs and interacting with customers, transformed operational processes, which ultimately allowed increasing the revenue stream.

\section{REFERENCES}

[1] J. Ross et al., CISR Designing digital organizations (2016).

[2] B. Giordano, O. Jones, AOM Family Entrepreneurial Teams: The Role of Learning in Business Model Evolution (2020).

[3] R. Casadesus-Masanell, J.E. Ricart, LRP From Strategy to Business Models and onto Tactics, p. 43 (2010).

[4] G. Ahuja, E. Novelli Res. red. and corp. strat. Incumbent responses to an entrant with a new business model: Resource co-deployment and resource re-deployment strategies (2016).

[5] T. Ritter, C. Lettl, LRP The wider implications of business-model research, 51 (2018).

[6] G.C. Kane et al. MIT Sl. Man. Rev. Strategy, not technology, drives digital transformation, p. 14 (2015) .

[7] H.S. Kang et al. Int. J. Prec. Eng. Man. Gr. Tech. Smart manufacturing: Past research, present findings, and future directions, 3 (2016).

[8] A. Osterwalder,Y. Pigneur. Business Model Generation. A Handbook for Visionaries, Game Changers, and Challengers (2013).

[9] R. Halenár et al. Act. Lud. Global Games: Production, Circulation And Policy In The Networked Era, p. 1 (2018).

[10] Brickipedia fandom: My LEGO Network (2020)

[11] LEGO: About Us (2020).

[12] The World's Most Valuable Brands, Forbes (2018)

[13] A.A. King, B. Baatartogtokh MIT Sl. Man. Rev. How useful is the theory of disruptive innovation? P. 57 (2015). 